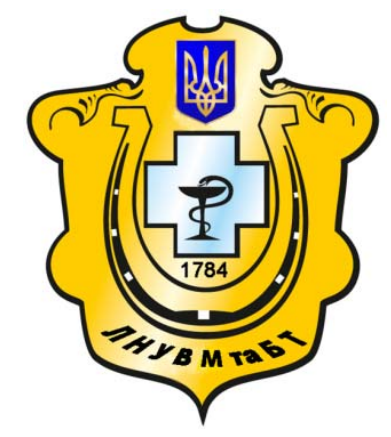

Науковий вісник Львівського національного університету ветеринарної медицини та біотехнологій імені С.З. Гжицького

Scientific Messenger of Lviv National University of Veterinary Medicine and Biotechnologies named after S.Z. Gzhytskyj

doi:10.15421/nvlvet7623

ISSN 2519-2701 print

ISSN 2518-1327 online

$\underline{\text { http://nvlvet.com.ua/ }}$

УДК 631.158

\title{
Фермерство - витоки розвитку: зональний аспект
}

\author{
М.Г. Шульський \\ pretty_62@mail.ru \\ Львівський національний університет ветеринарної медицини та біотехнологій імені С.3. Гжицького, \\ вул. Пекарська, 50, м. Львів, 79010, Україна
}

\begin{abstract}
Проведено дослідження діяльності фермерських господарств у Львівській області з урахуванням зональних аспектів їх розвитку. Основна мета даної публікачії полягає в тому, щзб привернути увагу науковців і практиків до дослідження процесів впливу природних факторів на розвиток аграрного виробництва. В основі иих досліджень - статистичні матеріали діяльності фермерських господарств у розрізі природних зон Львівщини: Полісся, Лісостепу, Передгірської і Гірської зон. В прочесах дослідження застосовано традиційні методи економічних досліджень: метод теоретичного обтрунтування, економіко-статистичного аналізу, монографічний, аналізу і синтезу та ін. В результаті досліджень встановлено, щцо у фермерських господарствах різних природних зон функиіонує різна кількість иих господарств (табл. 1), вони використовують різні за розмірами земельні угіддя (табл. 2, табл. 3), в них зайнята неоднакова кількість працюючих (табл. 4). Все це в комплексі дозволило встановити певні тенденції і закономірності формування циих господарств, які становлять основи їх розвитку. Висновки випливають із результатів дослідження і характеризують різні ознаки становлення фермерських господарств з урахуванням зональних аспектів. Для обтрунтування наслідків і відповіді на питання: чому це сталося так, а не інакше? - необхідно проводити подальші дослідження за обраною темою.

Ключові слова: фермерські господарства, природні зони, сільськогосподарські угіддя, рілля, виробничтво, праччівники.
\end{abstract}

\section{Фермерство - истоки развития: зональный аспект}

\author{
Н.Г. Шульский \\ pretty_62@mail.ru
}

Львовский национальный университет ветеринарной медиџины и биотехнологий имени С.3. Гжиџкого, ул. Пекарская, 50, г. Львов, 79010, Украина

\begin{abstract}
Проведено исследование деятельности фермерских хозяйств во Львовской области с учетом зональных аспектов их развития. Основная цель данной публикации состоит в том, чтобы привлечь внимание ученых и практиков к исследованию процессов влияния природных факторов на развитие аграрного производства. В основе этих исследований - статистические материаль деятельности фермерских хозяйств в разрезе природных зон Львовщины: Полесье, Лесостепи, Предгорной и Горной зон. В проиессах исследования использованы традичионные методы экономических исследований: метод теоретического обоснования, экономико-статистического анализа, монографический, анализа и синтеза и др. В результате исследований установлено, что в фермерских хозяйствах разных природных зон функционирует разное количество этих хозяйств (табл. 1), они используют различные по размерам земельные угодья (табл. 2, табл. 3), в них занято неодинаковое количество работающих (табл. 4). Все это в комплексе позволило установить определенные тенденщии и закономерности формирования этих хозяйств, которые составляют основу их развития. Выводы вытекают из результатов исследования и характеризуют различные признаки становления фермерских хозяйств с учетом зональных аспектов. Для обоснования последствий и ответа на вопрос: почему это произошло так, а не иначе? - необходимо проводить дальнейшие исследования по избранной теме.
\end{abstract}

Ключевые слова: фермерские хозяйства, природные зоны, сельскохозяйственные угодья, пашня, производство, работники.

Citation:

Shulskyi, M.G. (2017). Farming - the origins of development: the zonal dimension. Scientific Messenger LNUVMBT named after S.Z. Gzhytskyj, 19(76), 118-123. 


\title{
Farming - the origins of development: the zonal dimension
}

\author{
M.G. Shulskyi \\ pretty_62@mail.ru \\ Lviv National University of Veterinary Medicine and Biotechnologies named after S.Z. Gzhytskyi, \\ Pekarska Str., 50, Lviv, 79010, Ukraine
}

\begin{abstract}
This article presents the study of farms in the Lviv region, taking into account the zonal aspects of their development. The main purpose of this publication is to attract researchers and practitioners to study the processes of influence of environmental factors on the development of agricultural production. The basis of these studies used statistical materials farming activities in the context of natural areas in the Lviv region: Polesie, forest-Steppe, Foothill and Mountain areas. The study used traditional methods of economic research, the method of theoretical studies, economic and statistical analysis, monographic, analysis and synthesis, and others. As a result of studies found that farms of various natural zones operate a different number of farms (tabl. 1), they use different size plots of land (tabl. 2, tabl. 3), they occupied unequal number of working (tabl. 4). All of this together revealed certain trends and patterns of forming these farms, which are the foundations of development. The findings emerge from the study and characterize the different signs of becoming farmers, taking into account aspects zone. To substantiate the effects and to answer the question why this was so and not otherwise? It is necessary to carry out further research on the chosen topic.
\end{abstract}

Key words: farms, natural areas, agricultural land, arable land, production, workers.

\section{Вступ}

Результативність проведення аграрних реформ залежить від впливу цілого комплексу різноманітних факторів, важливу роль серед яких відіграють фактори зональності. Сільське господарство, як відомо, як ні одна галузь національного господарства, залежить передусім від природних умов, сукупність яких і формує відповідні природні зони. Саме на ці особливості в період здійснення реформування аграрних відносин недостатньо зверталась увага, особливо в системі наукових досліджень. Через ці обставини виникла об'єктивна необхідність надолужити те, що прогаяне в минулі роки, тобто прослідкувати, які особливості ведення аграрного виробництва спостерігаються 3 урахуванням зональності території. Ці процеси передбачено розглянути на прикладі розвитку фермерства Львівщини.

Мета і завдання дослідження. Мета публікації полягає у дослідженні формування і діяльності фермерських господарств з урахуванням наявності на території Львівської області природних зон: Полісся, Лісостеп, Передгірської і Гірської і тим самим привернути увагу науковців та практиків до зональних аспектів аграрного виробництва. Для виконання поставлених завдань використано матеріали статистичних органів, обробку яких проведено із застосуванням різних прийомів і методів економічних досліджень. На основі проведених досліджень передбачається зробити певні узагальнення і висновки.

Аналіз останніх досліджень і публікащій. Як було відзначено раніше, в сучасних умовах недостатньо звертається увагу на проведення досліджень функціонування різних аграрних форм господарювання 3 урахуванням зональності їх розміщення. Вченіаграрники концентрують увагу в основному на загальних аспектах розвитку різних організаційногосподарських структур у системі АПК, і майже поза увагою залишаються природні фактори впливу. Прикладом можуть бути дослідження таких відомих економістів-аграрників, як: А.Я. Месель-Веселяка,
М.Й. Маліка, С.М. Кваші, П.Т. Саблука, В.В. Липчука, Г.В. Черевка, П.М. Музики та інших. Саме такий стан ведення наукових досліджень розвитку аграрного сектору економіки обумовив необхідність у підготовці даної публікації.

\section{Результати та їх обговорення}

Про зональні аспекти, їх роль у різних сферах суспільних відносин сказано і написано багато. Не будемо вдаватися в конкретизацію цих категорій, а лише наведемо висловлювання В.В. Докучаєва (1846-1903), який проявив себе, «як видатний природознавець, основоположник сучасного грунтознавства..., досліджував грунти, рослинність і геологічні умови Полтавської губернїі..., заклав основи вчення про зони географічні..., розробив першу в світі природно-історичну класифікацію грунтів...» (Ukrainskyi radianskyi entsyklopedychnyi slovnyk, 1966). Ось що він відзначив: «...вода, земля, огонь (тепло и свет), воздух, а равно растительный и животный мир, благодаря астрономическому положению, форм и вращения нашей планеты вокруг ее, оси несут на своем общем характере явные, резкие и неизгладимые черты закона мировой зональности» (Dokuchaev, 1951). На основі сказаного стверджується, що: «основоположником сучасного вчення про зональність природи є В. Докучаєв, який обгрунтував причини зональності... та виділив основні географічні зони Землі» (Ukrainska radianska entsyklopediia, 1961).

Одночасно дещо уточнимо щодо 3'ясування суті зон географічних. В енциклопедичних виданнях про це сказано: «Зони географічні, природні зони - територіальні одиниці географічної оболонки, які мають вигляд широких смуг, простягаються на великих просторах земної поверхні та характеризуються спільними рисами фізико-географічних умов» (Ukrainska radianska entsyklopediia, 1961).

Отже, наукові дослідження проведені, здійснено певні узагальнення про зональність, залишилось тільки практично застосувати ці грандіозні напрацювання 
попередніх поколінь в сучасних умовах розвитку аграрного виробництва. Одночасно зауважимо, що за колишньої системи вчення про зональність використовувалось у процесах дослідження значно ширше і повніше, ніж у сучасних умовах. Чим це обумовлене? Насамперед тим, що проводити дослідження 3 використанням аспектів зональності є значно важче, ніж ці явища досліджувати в узагальнених показниках, скажімо, в розрізі окремих районів, регіонів чи держави в цілому. Вивчення тенденцій і закономірностей розвитку аграрного виробництва в розрізі природних зон $є$ досить копіткою справою, що супроводжується значними затратами часу на виборку і групування даних, проведення певних узагальнень на основі одержаних результатів, з одного боку, та їх узгодженості з висновками і узагальненнями теорії та практики щодо зональності - з іншого.

Все це, безумовно, здійснити значно важче, ніж провести економічні дослідження на основі загальних статистичних показниках розвитку тієї чи тієї форми господарювання в системі АПК. Отже, це складніше та більш утруднене проведення дослідження дозволяє діючі фактори зональності найповніше врахувати в процесах розвитку аграрного виробництва. Це настільки широка тема за охопленням розвитку господарюючого суб'єкта, з одного боку, та глибока за суттю, з іншого, що вимагає ії розчленування на окремі теми, підтеми, розділи, підрозділи і навіть окремі питання. Саме через ці обставини ми обрали за основу дослідження те, що становить фундамент функціонування будь-якої форми господарювання, а саме: земельні угіддя і наявність працівників, завдяки яким і здійснюються процеси використання земельних угідь для налагодження виробничої діяльності фермерських господарств Львівщини. Всі інші складові фермерського господарювання в розрізі природних зон необхідно досліджувати у наступних публікаціях. Це, зокрема, площі посівів сільськогосподарських культур, їх урожайність та ефективність ведення рослинницьких галузей, наявність поголів'я тварин, їх продуктивність та рентабельність виробництва тваринницької продукції, загальні показники розвитку фермерства тощо. I все це вимагає значних затрат часу і праці.

Отже, конкретизуємо наші результати досліджень. Перш за все, розглянемо наявність фермерських господарств у Львівській області в розрізі існуючих природних зон: Полісся, Лісостеп, Передгірської та Гірської зон. При цьому зауважимо, що нами у кожній зоні виділено окремі райони, які, на наше переконання, мають найбільш характерні ознаки зони, в якій вони знаходяться, 3 одного боку, та найбільшу кількість фермерських господарств, 3 іншого. Зібрані і певним чином оброблені матеріали представлені в таблиці 1. Для порівняльного аналізу використано інформацію про формування фермерства як форми ведення аграрного виробництва, починаючи із 2000 р., 3 концентрацією уваги на 2015 р.

Наведені дані показують, що найбільше фермерських господарств у Львівській області в 2000 р. було зосереджено у зоні Полісся - 507, дещо менше у лісостеповій зоні - 486, значно менше у Передгірській 151 і всього 20 у Гірській зонах, що у відсотковому відношенні ці величини відповідно складали: 43,6; 41,$7 ; 13 ; 1,7$. Щодо виділених районів: Сокальський (Полісся) - це найбільший за територією і найбільш потужний за ресурсами аграрного розвитку район Львівської області, в якому у 2000 р. функціонувало найбільше фермерських господарств - 177 одиниць і Пустомитівський (Лісостеп), який найближче розміщений навколо обласного центру м. Львова і має найбільшу за протяжністю межу з цим містом, отже - $€$ найближче до найбільшої чисельності споживачів аграрної продукції. Стрийський район найбільш розвинений у Передгірській, а Сколівський - у Гірській зонах Львівщини.

Наявність фермерських господарств у Львівській області та їх структура в зональному розрізі *

\begin{tabular}{|c|c|c|c|c|c|c|}
\hline \multirow{2}{*}{$\begin{array}{c}\text { Природні зони і виділені в них } \\
\text { райони }\end{array}$} & \multicolumn{2}{|c|}{$2000 \mathrm{p}}$. & \multirow{2}{*}{$2010 \mathrm{p}$} & \multicolumn{2}{|c|}{$2015 \mathrm{p}}$. & \multirow{2}{*}{$\begin{array}{c}2015 \text { p. y } \\
\% \text { до } 2000 \\
\text { p. }\end{array}$} \\
\hline & $\begin{array}{c}\text { кількість } \\
\text { господарств }\end{array}$ & $\begin{array}{c}\text { y \% до підсу- } \\
\text { мку }\end{array}$ & & $\begin{array}{c}\text { кількість } \\
\text { господарств }\end{array}$ & $\begin{array}{c}\text { y \% до } \\
\text { підсумку }\end{array}$ & \\
\hline Полісся - всього & 507 & 43.6 & 405 & 411 & 39,4 & 81,7 \\
\hline у тому числі Сокальський & 177 & 15,2 & 95 & 90 & 8,6 & 50,8 \\
\hline Лісостеп - всього & 486 & 41.7 & 451 & 502 & 48,1 & 103,3 \\
\hline у тому числі Пустомитівський & 143 & 12,3 & 105 & 113 & 10,8 & 79,0 \\
\hline Передгірська - всього & 151 & 13,0 & 95 & 126 & 12,0 & 83,4 \\
\hline у тому числі Стрийський & 74 & 6,4 & 50 & 61 & 5,8 & 82,4 \\
\hline Гірська - всього & 20 & 1,7 & 5 & 5 & 0,5 & 25,0 \\
\hline у тому числі Сколівський & 7 & 0,1 & 4 & 4 & 0,4 & 57,2 \\
\hline $\begin{array}{l}\text { Разом по фермерських госпо- } \\
\text { дарствах області }\end{array}$ & 1164 & 100,0 & 956 & 1044 & 100,0 & 89,7 \\
\hline
\end{tabular}

Примітка: * тут і надалі використано матеріали статистичного збірника (Zymovina, 2016)

Щодо змін наявності фермерських господарств у розрізі природних зон Львівської області за досліджуваний період, то можна констатувати таке:

- в зоні Полісся - якщо у 2000 р. була найбільша кількість фермерських господарств, то у 2010 р. їх зменшилось на 102 одиниці, а у 2015 р. відбулось деяке збільшення (всього на 6 господарств порівняно з 2010 р.), однак досягти рівня їх за кількістю 2000 р. не вдалося;

- в зоні Лісостепу - хоча закономірність аналогічна, однак значно відмінна в цифрових величинах - зменшення їх кількості у 2010 р. сягнуло всього 35 
господарств, а у 2015 р. кількість їх збільшилась до 502 одиниць, що на 3,3\% більше, ніж у 2000 р., a їх питома вага складала 48,1 \% у загальній кількості, тимчасом як питома вага фермерських господарств поліської зони знизилась до 39,4\% (дані 2015 р.);

- в Передгірській і Гірській зонах також відбулись аналогічні зміни, хоча менші в абсолютних показниках, однак відчутні у відносних вимірах, особливо це відобразилось щодо змін кількості фермерських господарств у Гірській зоні;

Зміни, що відбулись в кількості фермерських господарств у розрізі природних зон, вплинули на їх загальну наявність у досліджуваних роках. У цілому спостерігається зменшення кількості фермерських господарств із 1164 одиниць у 2000 р. до $1044-$ у 2015 р., або зменшення становило 10,3\%.

Формування фермерських господарств у тій чи тій зоні обумовлено насамперед наявністю відповідних площ земельних угідь, передусім сільськогосподарського призначення. Звідси цілком закономірно постає питання, а якими площами сільськогосподарських угідь були обділені фермерські господарства за досліджуваний період? Відповідь на поставлене питання дають матеріали таблиці 2, які тісно пов'язані із даними попередньої таблиці 1.

Площі сільськогосподарських угідь та їх структура в розрізі природних зон у фермерських господарствах Львівщини

\begin{tabular}{|c|c|c|c|c|c|c|}
\hline \multirow{2}{*}{$\begin{array}{c}\text { Природні зони і виділені } \\
\text { в них райони }\end{array}$} & \multicolumn{2}{|c|}{$2000 p$} & \multirow{2}{*}{2010 р., га } & \multicolumn{2}{|c|}{$2015 \mathrm{p}}$. & \multirow{2}{*}{$\begin{array}{c}2015 \text { р у \% до } \\
2000 \text { p. }\end{array}$} \\
\hline & га & $\begin{array}{c}\text { y \% до } \\
\text { підсумку }\end{array}$ & & га & $\begin{array}{c}\text { y \% до } \\
\text { підсумку }\end{array}$ & \\
\hline Полісся - всього & $\frac{19304^{*}}{38,1^{* *}}$ & $\frac{37,0}{x}$ & $\frac{26044}{64,3}$ & $\frac{22805}{555}$ & $\frac{43,6}{x}$ & $\frac{118,1}{145,7}$ \\
\hline $\begin{array}{l}\text { у тому числі } \\
\text { Сокальський }\end{array}$ & $\frac{7238}{40,9}$ & $\frac{13,9}{x}$ & $\frac{9214}{97,0}$ & $\frac{8147}{90,5}$ & $\frac{15,6}{x}$ & $\frac{112,6}{221,3}$ \\
\hline Лісостеп - всього & $\frac{24091}{49,6}$ & $\frac{46,2}{x}$ & $\frac{22650}{50,2}$ & $\frac{24473}{48,8}$ & $\frac{40,7}{x}$ & $\frac{101,6}{98,4}$ \\
\hline $\begin{array}{l}\text { у тому числі } \\
\text { Пустомитівський }\end{array}$ & $\frac{1756}{12,3}$ & $\frac{3,4}{x}$ & $\frac{1891}{18,0}$ & $\frac{3622}{32,1}$ & $\frac{6,9}{x}$ & $\frac{206,3}{261,0}$ \\
\hline Передгірська - всього & $\frac{8614}{57,0}$ & $\frac{16,5}{x}$ & $\frac{5273}{55,5}$ & $\frac{5019}{39,8}$ & $\frac{9,6}{x}$ & $\frac{58,3}{69,8}$ \\
\hline $\begin{array}{l}\text { У тому числі } \\
\text { Стрийський }\end{array}$ & $\frac{7525}{101,7}$ & $\frac{14,4}{x}$ & $\frac{2826}{56,5}$ & $\frac{3173}{52,0}$ & $\frac{6,1}{x}$ & $\frac{42,2}{51,1}$ \\
\hline Гірська - всього & $\frac{127}{6,3}$ & $\frac{2,3}{x}$ & $\frac{99}{12,8}$ & $\frac{54}{10,8}$ & $\frac{0,1}{\mathrm{x}}$ & $\frac{42,5}{171,4}$ \\
\hline $\begin{array}{l}\text { У тому числі } \\
\text { Сколівський }\end{array}$ & $\frac{30}{4,3}$ & $\frac{0,1}{\mathrm{x}}$ & $\frac{24}{6,0}$ & $\frac{54}{10,8}$ & $\frac{0,1}{x}$ & $\frac{180}{251,2}$ \\
\hline $\begin{array}{l}\text { Разом по фермерських } \\
\text { господарствах області }\end{array}$ & $\frac{52136}{44,8}$ & $\frac{100,0}{x}$ & $\frac{52066}{54,5}$ & $\frac{52348}{50,1}$ & $\frac{100,0}{x}$ & $\frac{100,4}{111,8}$ \\
\hline
\end{tabular}

Примітки: * чисельник - площі сільськогосподарських угідь - всього, га;

**знаменник - площі сільськогосподарських угідь в розрахунку на одне фермерське господарство, га

Наведені дані відображають певні тенденції змін площ сільськогосподарських угідь як у розрізі виділених природних зон, так в окремо виділених районах у них. Так, скажімо, у фермерських господарствах зони Полісся у 2000 р. було цих угідь 19304 га, у 2010 р. їх площі збільшились до 26044 га, а в 2015 р. зменшились до 22805 га, однак це зменшення все-таки обумовило зростання площ у 2015 р. порівняно з 2000 р. на 18,1 \%. Аналогічні тенденції спостерігаються у Сокальському районі, а також площ сільськогосподарських угідь в розрахунку на одне фермерське господарство. Не спостерігається істотних відмінностей і в інших природних зонах Львівщини.

Серед складових площ сільськогосподарських угідь найбільш продуктивними є площі ріллі, наявність якої, iї структура, а також скільки її припадає на одне фермерське господарство Львівщини - все це представлено у таблиці 3. Порівнюючи цифрові величини таблиці 2 і 3 можна пересвідчитись, що корінних відмінностей не спостерігається.
Проте привертають увагу показники щодо наявності орних земель в розрахунку на одне фермерське господарство від 2,3 га у Сколівському у 2000 р. до 92,1 га в 2010 р. у Сокальському районі. Тут спостерігається тверда закономірність - чим сприятливіші природні умови ведення аграрного виробництва, тим більше припадає земельних угідь на одне фермерське господарство і навпаки.

Характерною особливістю розвитку фермерства в зональному аспекті є не тільки наявність господарств, земельних угідь в кожній природній зоні, а й чисельність працівників, що зайняті у фермерській діяльності, які саме використовують наявні природні ресурси для ведення аграрного виробництва.

Такі обставини обумовили необхідність проведення досліджень щодо наявності працівників у фермерських господарствах Львівщини взагалі і в розрізі природних зон та виділених районах у них зокрема. 
Таблиця 3

Площі ріллі та їі структура в розрізі природніх зон у фермерських господарствах Львівщини

\begin{tabular}{|c|c|c|c|c|c|c|}
\hline \multirow[b]{2}{*}{$\begin{array}{l}\text { Природні зони та виді- } \\
\text { ленні в них райони }\end{array}$} & \multicolumn{2}{|c|}{$2000 \mathrm{p}}$. & \multirow[b]{2}{*}{$2010 \mathrm{p}}$. & \multicolumn{2}{|c|}{$2015 \mathrm{p}$} & \multirow{2}{*}{$\begin{array}{l}2015 \text { p. y \% } \\
\text { до } 2000 \text { p. }\end{array}$} \\
\hline & га & $\begin{array}{c}\text { у \% до } \\
\text { підсумки }\end{array}$ & & га & $\begin{array}{c}\text { у \% до } \\
\text { підсумку }\end{array}$ & \\
\hline Полісся - всього & $\frac{16989^{*}}{33,5^{* *}}$ & $\frac{39,5}{x}$ & $\frac{23891}{59,0}$ & $\frac{21616}{52,6}$ & $\frac{44,8}{x}$ & $\frac{127,2}{157,0}$ \\
\hline $\begin{array}{l}\text { у тому числі } \\
\text { Сокальський }\end{array}$ & $\frac{6254}{35,3}$ & $\frac{14,6}{x}$ & $\frac{8751}{92,1}$ & $\frac{7572}{84,1}$ & $\frac{15,7}{x}$ & $\frac{121,1}{238,2}$ \\
\hline Лісостеп - всього & $\frac{19246}{39,6}$ & $\frac{44,8}{x}$ & $\frac{18616}{41,2}$ & $\frac{21901}{43,6}$ & $\frac{45,3}{x}$ & $\frac{113,8}{175,3}$ \\
\hline $\begin{array}{l}\text { у тому числі } \\
\text { Пустомитівський }\end{array}$ & $\frac{1571}{20,3}$ & $\frac{3,7}{x}$ & $\frac{1826}{17,4}$ & $\frac{3509}{31,1}$ & $\frac{7,3}{x}$ & $\frac{120,9}{153,2}$ \\
\hline Передгірська - всього & $\frac{6639}{44,0}$ & $\frac{15,4}{x}$ & $\frac{4945}{52,1}$ & $\frac{4725}{37,5}$ & $\frac{9,8}{x}$ & $\frac{71,2}{85,2}$ \\
\hline $\begin{array}{l}\text { у тому числі } \\
\text { Стрийський }\end{array}$ & $\frac{5689}{76,9}$ & $\frac{13,2}{x}$ & $\frac{2622}{52,4}$ & $\frac{3017}{49,5}$ & $\frac{6,2}{x}$ & $\frac{53,0}{64,4}$ \\
\hline Гірська - всього & $\frac{107}{5,4}$ & $\frac{0,3}{x}$ & $\frac{18}{3,6}$ & $\frac{44}{8,8}$ & $\frac{0,1}{x}$ & $\frac{41,1}{16,4}$ \\
\hline $\begin{array}{l}\text { у тому числі } \\
\text { Сколівський }\end{array}$ & $\frac{16}{2,3}$ & $\frac{0,0}{\mathrm{x}}$ & $\frac{13}{3,2}$ & $\frac{44}{8,8}$ & $\frac{0,1}{\mathrm{x}}$ & $\frac{275,0}{382,6}$ \\
\hline $\begin{array}{l}\text { Разом по фермерських } \\
\text { господарствах області }\end{array}$ & $\frac{42981}{36,9}$ & $\frac{100,0}{x}$ & $\frac{47470}{49,7}$ & $\frac{48286}{46,3}$ & $\frac{100,0}{x}$ & $\frac{112,3}{125,5}$ \\
\hline
\end{tabular}

Примітки: * чисельник - площі ріллі фермерських господарствах, га;

** знаменник - площі на ріллі у розрахунку на одне фермерське господарство, га

Таблицяя 4

Наявність та структура зайнятих працівників в розрізі природних зон у фермерських господарствах Львівщини

\begin{tabular}{|c|c|c|c|c|c|c|}
\hline \multirow{3}{*}{$\begin{array}{c}\text { Природні зони та } \\
\text { виділені в них райони }\end{array}$} & \multirow{2}{*}{\multicolumn{2}{|c|}{2005 p. }} & \multirow[b]{3}{*}{$2010 \mathrm{p}}$. & \multirow{2}{*}{\multicolumn{2}{|c|}{$2015 \mathrm{p}$}} & \multirow{3}{*}{$\begin{array}{l}2015 \text { p. y \% } \\
\text { до } 2005 \text { p. }\end{array}$} \\
\hline & & & & & & \\
\hline & $\begin{array}{c}\text { чисельність праці- } \\
\text { вників, осіб }\end{array}$ & $\begin{array}{l}\text { у \% до } \\
\text { підсумку }\end{array}$ & & $\begin{array}{l}\text { чисельність пра- } \\
\text { цівників, осіб }\end{array}$ & $\begin{array}{l}\text { у \% до } \\
\text { підсумку }\end{array}$ & \\
\hline \multirow{2}{*}{ Полісся - всього } & $\underline{1977}$ & $\underline{43,4}$ & $\underline{1102}$ & $\underline{915}$ & 39,1 & $\underline{46,3}$ \\
\hline & 610 & $\overline{13,4}$ & 240 & $\overline{220}$ & $\overline{9,4}$ & $\overline{36,1}$ \\
\hline \multirow{2}{*}{$\begin{array}{l}\text { у тому числі } \\
\text { Сокальський }\end{array}$} & 552 & 12,1 & 200 & 179 & 7,6 & 32,4 \\
\hline & $\overline{181}$ & 4,0 & 33 & 32 & $\overline{1,4}$ & 17,7 \\
\hline \multirow{2}{*}{ Лісостеп - всього } & 2056 & 45,2 & 1022 & 1098 & 46,9 & 53,4 \\
\hline & 730 & 16,0 & 211 & 325 & 13,9 & 44,5 \\
\hline \multirow{2}{*}{$\begin{array}{l}\text { у тому числі } \\
\text { Пустомитівський }\end{array}$} & $\underline{333}$ & 7,3 & $\underline{340}$ & $\underline{410}$ & 17,5 & 123,1 \\
\hline & 124 & 2,7 & 45 & 79 & 3,4 & 63,7 \\
\hline \multirow{2}{*}{ Передгірська - всього } & 507 & $\underline{11,1}$ & $\underline{252}$ & 317 & 13,6 & 62,5 \\
\hline & $\overline{163}$ & $\overline{3,6}$ & $\overline{59}$ & $\overline{61}$ & 26 & $\overline{37,4}$ \\
\hline \multirow{2}{*}{$\begin{array}{l}\text { у тому числі } \\
\text { Стрийський }\end{array}$} & $\underline{222}$ & $\underline{4,9}$ & $\underline{98}$ & $\underline{86}$ & $\underline{3,7}$ & $\underline{38,7}$ \\
\hline & $\overline{71}$ & $\overline{1,6}$ & $\overline{24}$ & $\overline{22}$ & $\overline{0,9}$ & $\overline{31,0}$ \\
\hline \multirow{2}{*}{ Гірська - всього } & $\underline{12}$ & $\underline{0,3}$ & $\underline{16}$ & $\underline{10}$ & $\underline{0,4}$ & $\underline{83,0}$ \\
\hline & $\frac{12}{6}$ & $\frac{\overrightarrow{2}}{0,1}$ & $\frac{10}{6}$ & $\frac{10}{3}$ & $\frac{0,1}{0,1}$ & $\frac{5,0}{50,0}$ \\
\hline \multirow{2}{*}{$\begin{array}{l}\text { у тому числі } \\
\text { Сколівський }\end{array}$} & $\underline{12}$ & $\underline{0,3}$ & $\underline{8}$ & $\underline{7}$ & $\underline{0,3}$ & $\underline{58,3}$ \\
\hline & $\overline{6}$ & $\overline{0,1}$ & $\overline{3}$ & $\overline{2}$ & $\overline{0,1}$ & $\overline{33,3}$ \\
\hline \multirow{2}{*}{$\begin{array}{l}\text { Разом по фермерських } \\
\text { господарствах області }\end{array}$} & $\underline{4552}$ & $\underline{100,0}$ & 2392 & $\underline{2340}$ & 100,0 & $\underline{51,4}$ \\
\hline & $\overline{1509}$ & $\overline{33,1}$ & $\overline{516}$ & $\overline{609}$ & $\overline{26,0}$ & $\overline{40,4}$ \\
\hline
\end{tabular}

Примітки: * чисельник - наявність працівників усього, осіб; **знаменник - у тому числі жінок

Крім того, нами звернуто увагу на використання праці жінок у фермерській господарці. Оброблена певним чином інформація подана в таблиці 4. При цьому зазначимо, що ми не використали дані за 2000 р. (як у попередніх таблицях) тому що в статистичних збірниках інформація про ці показники за цей рік відсутня. I тому за висхідну основу прийнято 2005 p.

Наведені дані показують, що у фермерському господарстві як у цілому в Львівській області, так і в розрізі природних зон і виділених районах у них найменшу питому вагу становлять жінки - в межах третини 3 деяким відхиленням як у менший, так і більший бік. Ще одна характерна особливість випливає із даних досліджень про зміни, які відбулись в абсолютних i відносних величинах чисельності працюючих. А ці зміни вплинули на формування певних тенденцій $\mathrm{i}$ закономірностей, які полягають в тому, що загальна чисельність працівників у фермерських господарствах зменшувалася меншими темпами, ніж чисельність жінок у них. Тобто жіноча праця витісняється із фермерської діяльності більш інтенсивніше, ніж чоловіча.

\section{Висновки}

Узагальнюючи вищесказане можна констатувати таке: 
1. Ведення аграрного виробництва залежить насамперед від впливу природних факторів. I саме через ці обставини їх дію слід результативно використовувати як для введення фермерської, так і інших форм господарювання в системі АПК.

2. Аналіз розвитку фермерства Львівщини (за 2000-2015 рр.) в розрізі наявних природних зон (Полісся, Лісостепу, Передгірської і Гірської) показав, що на їх територіях розміщена неоднакова кількість фермерських господарств, які володіють різними площами земельних угідь як в абсолютному, так і відносному обчисленнях. У цих господарствах працює різна кількість осіб взагалі і жінок зокрема. При цьому характерним є те, що їх чисельність динамічно зменшується, при цьому зменшення жінок відбувається інтенсивніше, ніж чоловіків.

Перспективи подальших досліджень. В процесі проведених досліджень нами встановлено певні тенденції і закономірності щодо формування і діяльності фермерських господарств Львівщини в розрізі наявних природних зон на їх території. При цьому розглянуто питання щодо кількості фермерських господарств, наявності в них земельних угідь та чисельності працюючих осіб взагалі і жінок зокрема. Звідси цілком закономірно виникає питання: чому це сформувалось так, а не інакше? Дати відповідь на поставлене питання можна лише тоді, коли продовжити подальші дослідження розвитку фермерства як у загальних аспектах, так і в розрізі природних зон у Львівській області. Ця проблема є досить широка за темою дослідження та глибока за суттю їі розкриття i тому вимагає розробки всебічних напрямів іiі до- слідження, а одержані результати будуть основою для iii розв'язання.

\section{Бібліографічні посилання}

Horovyi, V.P. (2007). Efektyvnist fermerskykh hospodarstv lisostepovoi zony Ukrainy. K.: NNTs IAE (in Ukrainian).

Dokuchaev, V.V. (1951). Preobrazovanie prirody stepej. Raboty po issledovaniju pochv i ocenke zemel', uchenie o zonal'nosti i klassifikacii pochv 1888-1900. Izd-vo Akad. nauk SSSR. M.: L. (in Russian).

Maksymets, N.Iu. (2016). Osoblyvosti, chynnyky ta funktsii tovarnoi polityky fermerskykh hospodarstv N.Iu. Maksymets. Naukovyi visnyk Lvivskoho natsionalnoho universytetu veterynarnoi medytsyny ta biotekhnolohii imeni S.Z. Gzhytskoho. Seriia: ekonomichni nauky. 18, 2(69), 92-95 (in Ukrainian).

Zymovina, S.I. (2016). Silske hospodarstvo Lvivskoi oblasti. Statystychnyi zbirnyk. Lviv (in Ukrainian).

Ukrainskyi radianskyi entsyklopedychnyi slovnyk (1966). Tom 1. K.: Holovna redaktsiia Ukrainskoi radianskoi entsyklopedii AN URSR (in Ukrainian).

Ukrainska radianska entsyklopediia (1961). Tom 5. K.: Holovna redaktsiia Ukrainskoi radianskoi entsyklopedii (in Ukrainian).

Shulskyi, M.H. (2004). Fermerstvo: problemy stanovlennia i rozvytku. Monohrafiia. Lviv (in Ukrainian).

Стаття надійшла до редакиї 28.02.2017 